地すべり 第27卷 第 4 号

Journal of Japan Landslide Society 27-4 (1991)

\title{
臨界すべり面解析と信頼性解析を応用した 地すべり・崩壊危険度の判定法 \\ Landslide Susceptibility Estimation by Critical Slip Surface Analysis combined with Reliable Analysis
}

\author{
久保田 哲 也* \\ 中 村 浩 之** \\ Tetsuya KuBota \\ Hiroyuki NAKAMURA
}

\begin{abstract}
The detective method for landslide which occures suddenly without any sign seems to be important these days.

To this purpose, a estimation method using the critical slip surface analysis by dynamic programming combined with reliable analysis is established.

It might eliminate a error of unknown under ground condition, and can treat impact factor triggers landslide as well as slope nature, whereas it's not perfect. This method is useful to estimate the landslide susceptibility.
\end{abstract}

キーワード:危険度判定, マッピング, 地すべり調査, 安定解析

\section{1. はじめに}

日本列島は，激しい地殼運動の続く急峻な山地が国土 の大半を占め, 土砂災害に弱い体質を持つ上，可住面樻 も少ない。このような立地条件の国土に世界第二位の $\mathrm{G}$ NP を誇る活発な経済活動が営まれて拈り, 山地・丘陵 の宅地開発やリゾート開発等国土の有効利用が強く求め られていることから，地すべり・崩壊の危険性は增す一 方である。ところが，1984年 9 月の長野県西部地震で発 生した御岳崩れのような大規模崩壊や歴史に残っている 地すべり性大崩壊は，ほとんどすべてが，それまで発生 蕧歴のない斜面に生じる初生すべりである。また，地す ベりについても, 既往発生地すべりのうちかなりのもの が, 履歴のないものである

従って，初生すべりを判定し得る手法が確立されない 限り, 地すべりや地すべり性崩壊の危険籄所判定精度は 低いものに留ることになる。

そのため，土地利用規制など総合的な土砂災害対策を 進める上で, 初生すべりも含めた地すべり・崩壊の危険 箇所・危険度判定手法の確立が急がれておりここでは， そのような観点より, 発生危険箅所の判定が困難とされ る初生すべりの判定手法として, 動的計画法による臨界 すべり面解析と信頼性解析の応用を検討したので, 報告

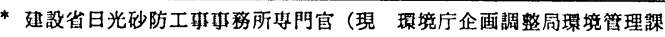
計画官)

**建設省土林研觉可地すべり研究室度（現 日本道路公団技術部調查 役）
する。

\section{2. 既往手法について}

地すべりや崩壊発生危険箇所を抽出する手法は，次の 二つに大別できる。

1) 直接法 (Direct Mapping)

地すべりや崩壊の分布状態を知って，それより危険籁 囲を抽出する。航空写真判読や現地調査より分布状態を 知り，それに基づき検討する方法2)。

2）間接法 (Indirect Mapping)

地すべりや崩壊の分布と関係なく, 勾配, 地質等の素 因あるいは誘因のみにより危険䉪所を抽出する方法3),4) 初生すべりを対象とする場合は，直接法よりも間接法 に依った方が，地すべり履歴に左右されなくて良いと思 われる。

このらち，安定解析を用いるものは，田中の手法 ${ }^{5)}$ Ward らの手法 $\left.{ }^{6}\right)$ のよらな無限長斜面モデルを用いて安 全率 $F_{S}$ の分布を得る手法が見られるのみである。これ らは，単純な直線状の斜面モデルであるから，地すべり のような大きな規模で深いすべり面を有するものには適 用できない。また，崩壊梁（風化土風厚）や地下水位を 把握せねばならず，これらはすべり面深さ・形状や重要 な誘因である地下水圧を未知としており，それらを与え る必要があり，これらの值を前もって正確に把握するの は不可能に近い。さらに重要な点は, この二つの手法で 求められた安全率 $F_{S}$ は, その斜面に打ける最小の安全 率であるとは限らない点である。 
上記の点を考慮し, 最小安全率とその時のすべり面を 任意の斜面に対して求められる臨界すべり面解析を用い, さらに未知要因の不確実性を評価に入れることのできる 信頼性の概念を応用した危険度判定手法を検討した。

\section{3. 臨界すべり面解析}

\section{1 臨界すべり面解析の流れ}

臨界すべり面解析とは, 与えられた地形・地質・土質 条件等に対して最小の安全率とその時のすべり面を任意 の安全率計算法（例えば Janbu 法や簡便分割法など） を用いて探索する手法のことである。Leshinsky ${ }^{7)}$ や鵜 飼8)の手法のように変分法を用い, 求積的に最小安全率 を持つすベり面つまり「臨界すべり面」を求める手法も あるが，この手法では, 臨界すべり面は対数螺旋解とし てのみ与えられ, 任意形状の臨界すべり面すなわち, 真 の意味での最小安全率を持つすべり面は得られない。

ここでは, 最近発展の著しい動的計画法 (Dynamic Programming) 理論を用いて探索範囲内で任意形状の臨 界すベり面が得られ, 種々の地䅉構造に適用し得る手法 を用いた。

\section{2 動的計画法 (以下, DP と略す。)}

DP とは, R. Bellman（1957）により開発された非線 型数学的計画法である。これは, 時間的一空間的多段階 最適問題を取り扱らものであり, 最適值（極值）を求め るには变分法などが有効だが，その多変数や微分不可能 な関数には不適といら限界や，線型計画の持つ非線型関 数に対する限界を解決する為に開発された。

DP の基本原理は，マルコフ性*)を持つ多段階決定過 程を次の汎関数 $G$ を最小化することに帰着させ, 最小汎 関数 $f_{n}$ を求めることである ${ }^{9)}$ 。

$$
\begin{aligned}
& f_{n}=\min \bar{G}=\min \left[\bar{G}_{0}+\min \sum_{i=1}^{n} \bar{G}_{i}\right] \\
& =\min \left[\bar{G}_{0}+f_{n-1}\right] \\
& f_{n-1}=f_{n}-\bar{G}_{0}
\end{aligned}
$$

ここに，iは多段階決定過程の各段階， $\bar{G}_{0}$ は， $\bar{G}$ の 利得 (return), $f_{n}$ は求める最小汎関数。

DP の概念は, 数多くの数学書に譲るが, その長所は, 前述したように非線型, 微分不可能な関数に適用できる 上に, 最適值すなわち最小汎関数 $f_{h}$ を求める過程（こ 場合は，すべり面探索過程）を共通の始点（すべり面探 索範囲の上端）と異なる終点（探索下端）を持つ問題族 に変換することによりすべての組み合わせで総当り計 算する必要を取り除いている点にある。

\section{3 安全率関数}

ここでは, 安全率を求めるのに必要な安全率関数に, 精度が良く, 計算時間の少なくて済む簡便 Janbu 法に

*) マルコフ性とは，確率過程等多段陼過程の段階の決定もしくは，現 象が，その直前の段階にのみ依存する性貝を言う。
より，非円弧すべりの計算ができる方法を用いた。この 方法は極限平衡法の分割法に属し, 図-1の分割スライス に働く力の均合から求めた。

$$
\begin{aligned}
F_{s}= & {\left[\sum \left[c_{i}{ }^{\prime} l_{i}{ }^{\prime} \cos \alpha_{i}+\left\{\left(1+k_{v}\right) W_{i}+\Delta X_{i}\right.\right.\right.} \\
& \left.\left.\left.-U_{i} l_{i} \cos \alpha_{i}\right\} \tan \phi_{i}{ }^{\prime}\right] / n \alpha_{i}\right] \\
& /\left[\sum\left[\left\{\left(1+k_{v}\right) W_{i}+\Delta X_{i}\right\} \tan \alpha_{i}+k_{H} W_{i}\right]\right]
\end{aligned}
$$

(3)式に，スライス間垂直抵抗力を一定としても実用上 さしつかえないとする仮定 $\left(\Delta X_{i}=0\right)$ を持ち込んで整 理すると,

$$
n \alpha_{i}=\cos ^{2} \alpha_{i}\left\{1+\tan \alpha_{i} \tan \phi_{i}{ }^{\prime} / F_{s}\right\}
$$

ここで, 図-1中の記号以外に, $F_{S}$ : 安全率, $C_{i}{ }^{\prime}: i$ 番 目のスライスの有効応力表示の粘着力, $l_{i}: i$ 番目のス ライスのすべり面長さ, $\alpha_{i}: i$ 番目のスライスの傾斜角, $\phi i^{\prime}: i$ 番目スライスの 有効応力表示内部摩擦角, $u_{i}$ : 間隙水圧。

従って, 安全率関数は次式となる。

$$
F_{s}=f_{0} \cdot \sum A_{i} / \sum B_{i}
$$

ここに $A_{i}$ : 抵抗成分, $B_{i}:$ 滑動成分。

$$
A_{i}=\left[c_{i}{ }^{\prime} l_{i} \cos \alpha_{i}+\left(W_{i}+k_{v} W_{i}\right) \cdot \tan \phi_{i}{ }^{\prime}\right] / n \alpha_{i}
$$

$$
B_{i}=\left(1+k_{v}\right) W_{i} \tan \alpha_{i}+k_{H} W_{i}
$$

ただし, 間隙水圧は, 地下水面下の土重量を有効重量 で計算する。また，修正係数 $f_{0}$ は，シ式で与えられ

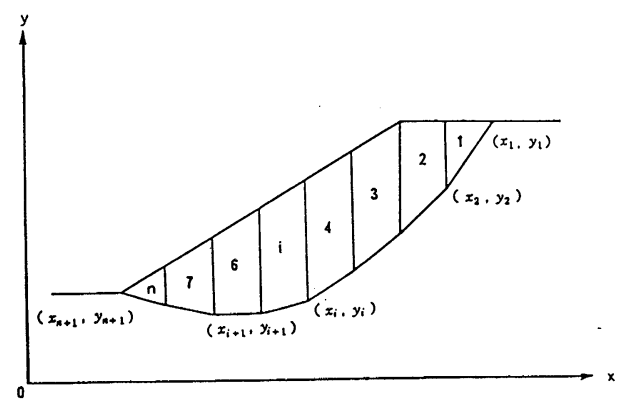

（a）地すへり土塊

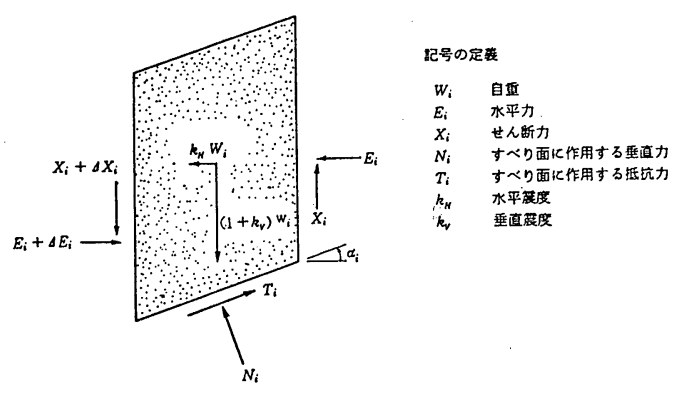

(b) スライス 亿作用するカ

図-1地すべり土塊及スライス説明図

Fig. 1 Schematic Diagram of Landslide Mass and Slice 
$3^{10)}$ 。

$f_{0}=(50 d / L)^{0.03}$

ここに，Lは直線距離で測ったすべり面長， $d$ は線分 $L$ に平行かつ, すべり面に接する線分と $L$ の距離。(4) (7)式に示す安全率関数は， $F_{S}$ について陰に定義されて いるので, 反復計算を行って求める。 $f_{0}$ も初期值 1.0 よ り反復計算するものである。

\section{4 安全率関数の最小化}

DP が，加法的関数のみに応用し得ることに着目すれ ば, 安全率の関数形は, 変分法における Euler 方程式の 線型汎関数と類似の関係となるので，その最小化は $\bar{G} の$ 最小化と同義となる(1),14)。

このように， $\bar{G}$ を最小化すれば，必然的に（ $\bar{B}>0$ で ある限り） $F_{S}$ を最小化することになる。従って， $\bar{G}$ 最小化するために DP の基礎式を演算すれば良い。そ れは，DP 理論より，(1)，(2)式を離散化した次式となる。

$$
\bar{G}_{i+1}(j)=\min _{K=1 \ldots K K_{i}}\left\{\bar{G}_{i}(K)+D G_{i}(K, j)\right\}
$$

ここに, $\bar{G}$ : 補助汎関数, $i:$ stage 番号, $j:$ state 番 号 (図-2参照)，K:ある stage $i$ から次の stage 上の 点へ到達し得るすべての交点を表わす。 $K K_{i}:$ stage $i$ における交点数。D $G_{i}$ は利得である。

ただ，ここでは，すべり面の始点と終点は最初から 分からないので, Baker ${ }^{11)}$ の考方方を採用し，変分問題 の端点条件をゆるくし，すべり面始点と終点を探索でき るようにした。

\section{5 計算手法}

ここまで述べてきた臨界すべり面解析と類似の方法で, Baker などは(1),12),13)，計算を行っているが，すべり面の 始点と終点が既知でなければならない，あるいは，上に 凸な異常なすべり面発生制限条件がない等の制約がある ので、これらに配慮した計算法を開発した。具体的には， 次の手順で行ら。

まず，(9)式の初期条件を次式で与える。

$$
\bar{G}_{i}(k)=0
$$

これは, 臨界すべり面探索初期は, 滑動 力も抵抗力もゼロであることを意味する。 これに漸化式 (9)式と, 安全率補助関数 $\bar{G}$ を用い，以下の計算を実行する。

（1）想定される臨界すべり面を含むよう に探索点 (stage, state) を設ける（図-2）。 これは, 分割スライスの鉛直線と対応させ る。

(2) 利得増分を次式より計算する。

$$
d G_{i j}=X_{i}-F_{s 0} \cdot B_{i} / f_{0}
$$

$F_{s 0}$ : 安全率の初期值 (通常 $F_{s_{0}}=1.0$ ) である。

（3）（23）式より利得を初期化する。

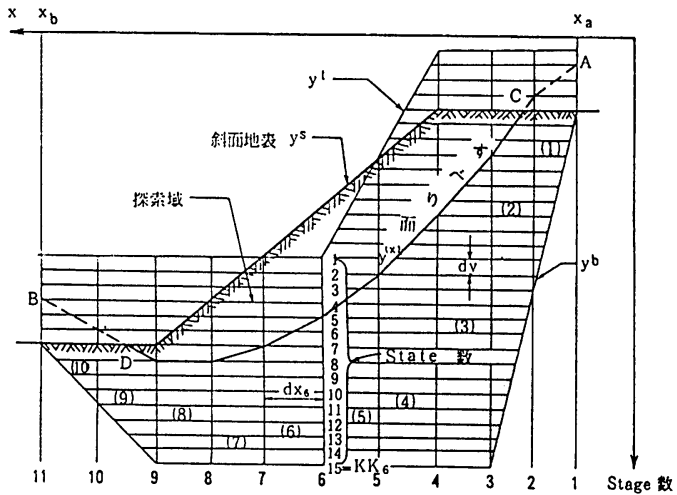

图-2 動的計画法 DP 亿対する斜面の離散化模式図

F!g. 2 Schematic Diagram of Discrete Slope for IJP

（4）（22）式より最小利得を計算し，その経路を記憶さ せておく。

（5）最終 stage すなわち臨界すべり面末端で最小利 得となっている state（図-2）を探す。

（6）一つ前の stage に打ける最小利得経路をメモリ 一より呼び出し, 臨界すべり面を求め, 安全率を与える。 ただし，異常なすべり面形状を制約するために次の条 件を選択できるようにする。

$\left(d^{2} y / d x^{2}\right)_{i} \geqq 0 \quad(i=1 \cdots \cdots n, n:$ スライス数 $)$

また， $n_{\alpha i}$ が負になると現実には存在し得ないすべり 面（つまり，すべり面抵抗力 $T_{i}$ (図-1) が負となるも の）が生じるので, これを排除するため,

$n_{\alpha i}>0$ つまり $\cos ^{2} \alpha_{i}>0$ より,

$F_{s}>-\tan \alpha_{i} \tan \phi_{i}{ }^{\prime}$ なる 条件を付す。

$\left(\because \quad T_{i}=\left[c_{i}{ }^{\prime} l_{i} \cos \alpha_{i}+\left\{\left(1+k_{v}\right) W_{i}+\Delta X_{i}\right.\right.\right.$ $\left.\left.-U_{i} l_{i} \cos \alpha_{i}\right\} \tan \phi_{i}{ }^{\prime}\right]$ $\left./\left(F_{s} \sec \alpha_{i} n \alpha_{i}\right)\right)$

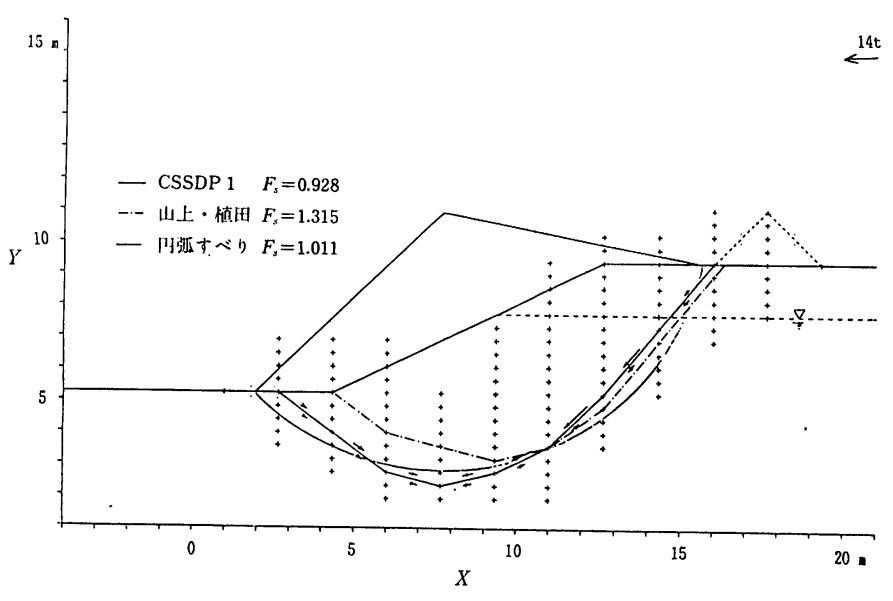

図-3 DP による臨界すべり面計算の検証

Fig. 3 Comparison Diagram of Critical Slip Surface Analysis by DP 
以上のような考方方に基づく, 電算プログラムを作成 した ${ }^{14)}$ 。

これを用いて，様々な事例計算を行ったが14)（図-3）, この手法（以後 CSSDP 1 と呼ぶ）で求めた安全率が, 他の手法で求めたものよりも小さい。しかも, 数值的に は異常なものではなく, 円弧すべり解析などと比較して も妥当なものとなっている。ただし，垂直のがけや，無 限長斜面に近いものなどでは, 計算結果が信頼できると は限らず，臨界すべり面が地表面と一致してしまらこと もある。

\section{4. 信頼性解析の導入}

地すべりや崩壊の安全率を推定するには, 当然, 地下 水位や地下構造, 想定地震力などを知らねばならないが, 初生すべりに対してこれらの要素を調べることは不可能 に近い。そこで, 信頼性解析の概念 ${ }^{15)}$ とよる統計的な考 え方をここに持ち込んで，未知な要素を未知としたまま 危険度の評価を行なう。

\section{1 信頼性の概念}

斜面の安定に関する信頼性は, 確率事象が正規分布で あると考えて，

$$
\begin{aligned}
& P[F]=1-\phi(\beta) \\
& \phi(\beta)=\frac{1}{\sqrt{2 \pi}} \int_{-\infty}^{\beta} e^{-t^{2 / 2}} d t \\
& \beta=\tilde{R}-\tilde{D} / \sqrt{V} \overline{a r} \overline{(R-D)}
\end{aligned}
$$

ここで, $\beta$ : 信頼性指数(崩壊発生限界值), $P[F]:$ 崩 壊の発生涪, $\phi(\beta)$ : 標準正規分布の累積分布関数 (CDF) で, 崩壊の発生しない確率, $t$ : 標準正規分布の確率変 数， $R$ : 抵抗力 $(\tilde{R}$ は，その集合的または空間的平均 值), $D:$ 滑動力 $\left(\tilde{D}\right.$ は $\tilde{R}$ と同義, $R$ と $D$ は(5)式の $\sum A_{i}$ と $\sum B_{i}$ に当る。), $V a r:$ 分散である。

$$
\operatorname{Var}(R-D)=\operatorname{Var}(R)-2 C_{o v}(R, D)+\operatorname{Var}(D)
$$

ここで $C_{o v}(R, D): R$ と $D$ の共分散である。

\section{2 初生すべり安全率の信頼性解析}

初生すべりの安全率を求める時, 最も不確実性の高い のは，どのような間隙水圧（地下水圧）あるいは地震力 が働くのかが断定できないことから，滑動力である。例 えば, 豪雨時の間隙水圧分布や融雪時のそれを調查対象 地域各斜面について知るのは実際上不可能であるし，地 震力もその大きさの上限を定めるのが難かしい。従って, ここでは，これら不確定要素を未知としたまま，平常時 の斜面外力条件 (滑動力が, 平常時の地下水条件下での 自重のみ）により計算した安全率つまり現状安全率によ り，地すべり・崩壊発生の危険度を判別することを試み る。

まず，上述の現状安全率を $F_{s c} l$ とし， $F_{s c} l=F_{s \max }$ と考学る。 $F_{s \max }$ ：確率分布をなす $F_{S}$ の事実上の最大
值。

$$
\begin{aligned}
& D \text { の変動係数は, } \\
& \qquad V_{\nu}=\sigma D / \tilde{D}=|\sqrt{\operatorname{Var}(D)}| / \tilde{D}=|\sqrt{\operatorname{Var}(D)} / \tilde{D}|
\end{aligned}
$$

ここに, $\sigma_{D}$ は $D$ の標準偏差である。

この時, 崩壊しない信頼係数は, (15), (16)式から, $R$ と $D$ が普通相関を持たないことを考えて， $\left(C_{o v}(R\right.$, $D)=0)$,

$$
\beta=(\tilde{R}-\tilde{D}) / \sqrt{\operatorname{Var}(R)+\operatorname{Var}(D)}
$$

ここで，対象としている $D$ と $R$ の不確実性は，想定 推定に伴ら不確実性であるから, 同レベルと考元て, $\operatorname{Var}(R) \doteqdot \operatorname{Var}(D)$ とする。

$$
\beta \doteqdot(\tilde{R}-\tilde{D}) / \sqrt{2 \operatorname{Var}(D)}
$$

これを変形して，

$$
\begin{aligned}
& \sqrt{\operatorname{Var}(D)} / \tilde{D}=(\tilde{R}-\tilde{D}) /(\sqrt{2} \cdot \beta \cdot \tilde{D}) \\
& \quad=(\tilde{R} / \tilde{D}-1) / \sqrt{2} \beta=\left(\tilde{F}_{s}-1\right) / \sqrt{2} \beta .
\end{aligned}
$$

ここに, $\tilde{F}_{s}$ は平均安全率である。

(17)式に(20)式を代入して，

$$
V_{D}=\left|\left(\tilde{F}_{s}-1\right) / \sqrt{2} \beta\right| \cdots
$$

(20)式より,

$$
\tilde{F}_{s}=\sqrt{2} \beta \cdot V_{D}+1 \cdot
$$

故に, $\beta$ と $V_{D}$ が与えられれば, 安全率 $F_{s}$ が求ま る。

$\tilde{F}_{s}$ を斜面周辺地域の平均的な安全率であると見なす と, CSSDP 1 で求めた $F_{s c} l$ が, $\tilde{F}_{s}$ よりる小ならば, 崩壊する危険度は周囲の斜面より高い結果となるので, $\tilde{F}_{s}$ は一種の基準安全率と呼べる。

次に, $\beta$ と $V_{D}$ について検討を行なう。

\section{$4.3 \beta$ の推定}

地すべり・崩壊発生率 $P[F]$ と，(13)式，(14）式を 使って，自然界で一般的に見られるようにエルゴート 性**) が保証されているものとして， $\beta$ を求める方法を 検討する。これは, あるひとつの斜面の地形発達過程で 生じる各斜面状態に対応する安全率の時系列的集団の平 均值は，地質条件の類似した周辺斜面を集合的に見た時 の各斜面の安全率集団の平均值にほぼ等としいと仮定す ることを意味する。言い換えれば，ある時点にある斜面 周辺には，様々な素因条件や外力条件下にある斜面が存 在し，それらは集合的に見れば，ある特定斜面の過去・ 未来のそれら条件にほぼ等しいものが存在し，それら各 斜面の安全率の集合平均は，考えている特定斜面の時系 列的な素因条件・外力条件の変化に対応した各安全率の 平均に等価であると考えることを意味する。この時系列 的な安全率の頻度分布が正規分布ならば, その平均值は, 最大值と最小值の平均すなわち $\left(F_{s \max }+F_{s \min }\right) / 2$ と見 なせる。

**) エルゴート性 : 集合的あるいは空間的平均量が，時間的平均量と等 価である性筫。 
既往の地すべり・崩壊発生頻度に関する調査より, 調 査対象と類似の素因条件を持つ地域の $P[F]$ を求め,

(13)式(14)式より $\beta$ を得ることができる。

$$
\beta: \phi(\beta)=1-P[F]
$$

$\beta$ は, 正規分布関数表より求まる。

当然， $\beta$ は誘因別にも求めるべきと考えられるが，各 地すべり・崩壊のすべてに記録が残っているわけでもな く, 通常航空写真判読など事後の調查で発生率を調査す ることより，P[F] を誘因別に求めるのは困難である。 そこで， $\beta$ は素因のバラつきを代表するものとし，誘因 のバラつきは次に述べるVDにより代表させる。

\section{$4.4 V_{D}$ の推定}

$V_{D}$ は，滑動力中の地震力や間隙水圧の見積りに関す る分散度を表わすので，比較的正確に計算された最大・ 最小安全率つまり真の最大・最小安全率 $F_{s \max }, F_{s \min }$ に近いものが計算されている事例より， $F_{s}$ が正規分布 するとして, 時系列的平均 $\tilde{F}_{s} \doteqdot\left(F_{s \max }+F_{s \min }\right) / 2$ と工 ルゴート性を考虑し，(21)式ならびに前節で求めた $\beta$ を

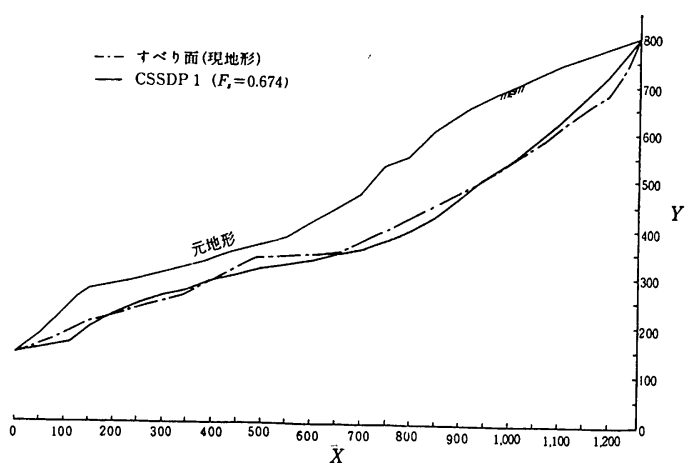

(a)

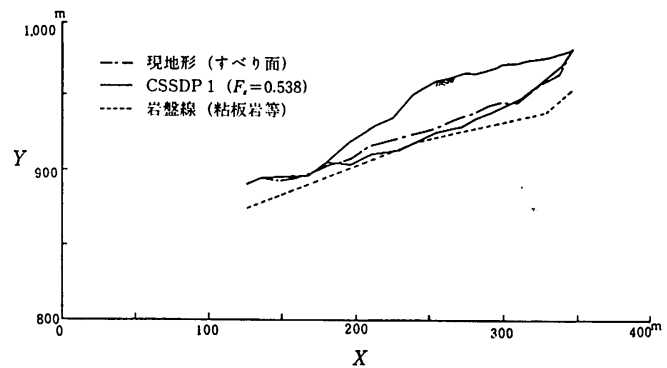

(b)

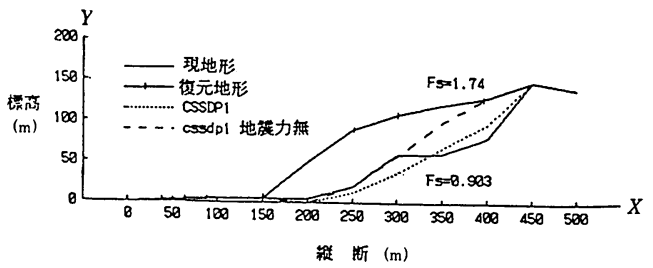

(d)
使用して求める。

\section{5. 事件解析}

$V D$ に対する評価を, 地震力が卓越するケースとそれ 以外 (豪雨・融雪) を対象とする場合とに分けて, それ ぞれの事例解析を行なら。

\section{1 地震力に関する事例}

真の $F_{s \min }$ に近いものが得られているものとして, 1984年 9 月の長野県西部地震 $(M=6.8)$ で発生し, 調 査のよくなされている16),17) 御岳崩れと松越地区の崩壊 等について検討する。

1）御岳崩れ16)：すべり面はパミス層， $M=6.8, C=$ $8.7 \mathrm{t} / \mathrm{m}^{2}, \phi=29^{\circ}$ 。

ほほ，同様な地質構造を持ち，大規模崩壊も有する ${ }^{18)}$ 日光火山群の女峰. 赤雉山崩壊 発生率 0.018 (面積 率 ${ }^{19)}$ と, (23)式より, $\beta \doteqdot 2.10$ 。地震力無しの時の CS SDP 1 計算值 $F_{s c} l$ を $F_{s \max }$ と見なし， $F_{s \max } \doteqdot 1.21$, 次に地震力を印加した時の $F$ scl を $F_{s \min }$ とし, $F_{\text {smin }} \doteqdot$ 0.674 (図-4(a))， $\tilde{F}_{s}=\left(F_{s \max }+F_{s \min }\right) / 2 \doteqdot 0.942$ 。これ を，(21)式に代入して， $V_{D} \doteqdot 0.020$ を得る。

2）松越の崩壊 ${ }^{17)}$ ：すべり面はパミス層， $M=6.8$, $C=4.53 \mathrm{t} / \mathrm{m}^{2}, \phi=18.3^{\circ}$ 。

図-4(b)の臨界すべり面に対して, CSSDP 1 の地震力 印加 $F s c l=F_{s \min } \doteqdot 0.538$, 地震力無し $F s c l=F_{s \max } \doteqdot$ 1.28 で16), 御岳崩れと同様 $\beta=2.10$ より, $\tilde{F}_{s}=(1.28+$ $0.538) / 2 \doteqdot 0.909$ 。これより， $V_{D} \doteqdot 0.031$ 。

さらに，異なった地盤と震度に対して検討するために， 資料の整っており, 発生前復元斜面や震度, すべり面が 正確に推定できる次の例も示す。

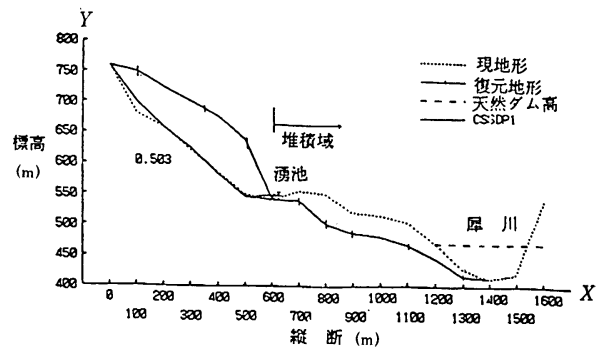

(c)

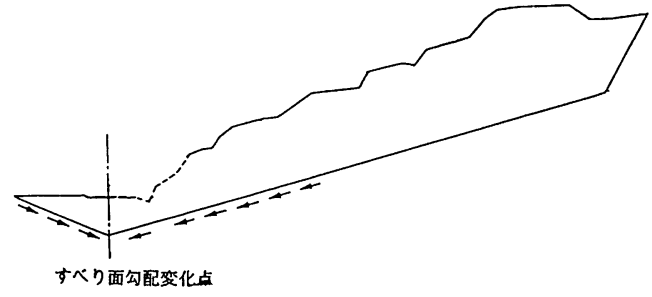

(e) 

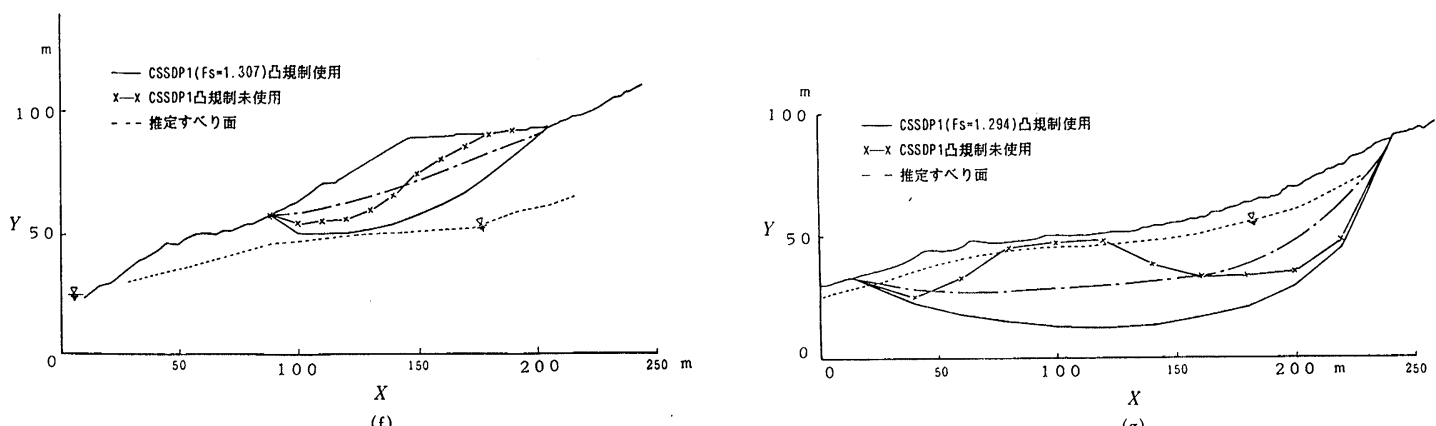

(f)

(g)

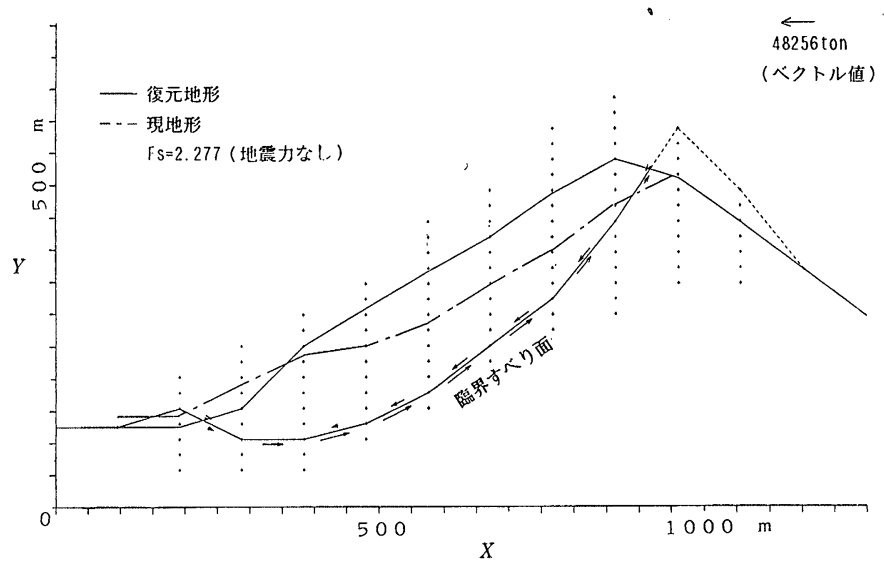

(h)

図-4 事 例 解 析

(a) 御岳崩れ, (b) 松越, (c) 虚空蔵山, (d) 名立, (e) 福島いわき, (f) 八崓, (g) 怒田, (h) 葛老山 Fig. 4 Example to determin VD Value

(a) Ontake, (b) Matsukoshi, (c) Kokuzouyama, (d) Nadachi, (e) Fukushima-Iwaki, (f) Yone

(g) Nuta, (h) Katsurouyama

3）長野市虚空蔵山神（図-4(c)）：すべり面は砂岩層, $M=7.4, C=2.6 \mathrm{t} / \mathrm{m}^{2}, \phi=21.5^{\circ}$ 。

この崩壊地は，砂岩の上に凝灰角碟岩が乗る互層構造 になっており，第三紀層に属しているから，同様な地質 を持つ新潟県長岡地区の地すべり発生率20)より, 平均值 $P[F] \doteqdot 0.216$, これより, $\beta \doteqdot 0.790$ で, $\operatorname{CSSDP} 1$ より, $F_{s \min } \doteqdot 0.503, F_{s \max } \doteqdot 1.22$ から， $\tilde{F}_{s} \doteqdot 0.862$ 。だから, $V_{D} \doteqdot 0.124$ 。

4) 名立崩れ ${ }^{16)}: 1751$ 年の地震 $(M=6.6)$ で発生し たもので（図-4(d))，崩壊土塊が日本海に突入して浸食 される等，資料的にも不明な点が多く，復元斜面すなわ ち, すべり面深さや, 稼働地震力が不確定ではあるが, $\operatorname{CSSDP} 1$ の結果は $C=11.9 \mathrm{t} / \mathrm{m}^{2}, \phi=29.7^{\circ}$ より $F_{s \min } \doteqdot$ $0.903, F_{\text {smax }} \doteqdot 1.74, \tilde{F}_{s} \doteqdot 1.32$ である。

名立崩れは，第三紀層の泥岩・砂岩・頁岩互層から成 る地質に発生しており, 新潟県の寺泊層に属するから, その発生率を使えば良いが，地質構造的に貫入岩など特 別なものではないことを考え, 長岡地区寺泊層のもの 20
を用い, $P[F] \doteqdot 0.380$ とする。

これより，(23）式を使い， $\beta \doteqdot 0.310$, そして $V_{D} \doteqdot$ 0.730 を得る。

これらの值は, 幅はあるものの, CSSDP 1 の地震力 印加時の臨界すべり面が推定すべり面と良く一致するこ とを考え合わせれば，地震力の見積りに関する変動係数 としては, $V_{D}<0.7$ 程度で良いと思われる。

\section{2 地震以外に関する事例}

1）福島県いわき市の地すべり（図-4(e)）

地下水位の不確定さによる $\beta$ を定めるには, 地下水位 または，水圧を測定しているケースがほとんど無いので， ここでは, 次の一例を示す。この事例は, 福島県いわき 市で発生し，すべり形状が平面的に左右対称に近い上， 土質調査や地下水調查の資料があり,すべり面がほぼ確 定されているので, 厳密な Morgenstern \& Price 法に よる安全率が求められている21)。CSSDP 1 とは異なる が，VD の推定には利用できる。この時, 地下水有・無 の $F_{s c l}$ は, $F_{s \min } \doteqdot 0.950, F_{s \max } \doteqdot 1.10$ である。故に, 
$\tilde{F}_{S} \doteqdot 1.03$ 。地質は, 強風化花崗岩で, 棚倉破砕帯周辺に 分布する阿武幔花崗岩の一種である。系魚川・静岡構造 線周辺の強風化花崗岩地域22) と類似すると思われるので, その $P[F]=0.023 \sim 0.046$ を使って, $\beta=2.0 \sim 1.68$, 上述の $\tilde{F}_{S}$ を用いると $V_{D}=0.0106 \sim 0.0126$ となる。

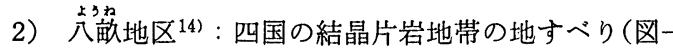
4(f)）で，移動時の地下水位が不確定であるもので，CS SDP 1 より $F_{s \max }=1.307$ ，臨界すべり面も実際の推定 すべり面より深くなる。 $\beta$ は，四国結晶片岩地带の発生 乘3) $P[F] \doteqdot 0.277$ より，(23)式から， $\beta \doteqdot 0.590 。 F_{\text {smin }}$ は求められていないが，移動中であるが変位が大でない ことから， $F_{s \min } \doteqdot 1.0$ を使うと， $\tilde{F}_{S} \doteqdot 1.15$ 。(21)式よ り, $V_{D} \doteqdot 0.180$ となる。

3）怒态地区 ${ }^{14)}$ : 八畧地区之同じ特徽を持ち, $\beta \doteqdot$ 0.590 と考㝋て良い。CSSDP 1 より $F_{\text {smax }} \doteqdot 1.294$ (図一 $4(\mathrm{~g}))$ 。八畧地区と同じく $F_{s \min } \doteqdot 1.0$ と考光られるから， $\tilde{F}_{S} \doteqdot 1.15$ ，(21)式より， $V_{D} \doteqdot 0.180$ が得られる。

2)と3)の事例に打ける臨界すべり面は，観測されてい るすべり面と一致しない。これは，この地区が塑性流動 的な運動をする ${ }^{23)}$ 薄いすべり面に乗って移 動するにもかかわらず，弱層が計算上与え られていないためである。

いずれにしても，これらの事例より，地 震に対する地すべり崩壊に対して，VID 0.7 程度を見込む他, 地下水位やすべり面 のみの不確定なものについても $V_{D} \leqq 0.2$ 程度を見込むことが必要と思われる。

\section{3 検証計算 (栃木県栗山村曷老山}

上述の危険度判定手法の検証として，栃 木県葛老山の崩壊について, 現地調査と史 料より復元を行い，その復元斜面を用いて， 検証計算を行って見た。

この崩壊地は，第三紀のグリーンタフよ り成り, 1683 年の地震 $(M=6.8)$ により 生じた。現地の露頭観察によると，走向は $\mathrm{N} 70^{\circ} \mathrm{W}$ 傾斜 $18^{\circ} \mathrm{W}$ の受盤 となっている が，岩盤は節理に富み破壊され易いものと なっている。この岩盤は $\mathrm{CH} \sim \mathrm{CM}$ クラス の硬さを持ち，一般的に岩盤分類表より ${ }^{24)}$, $\gamma=2.6 \mathrm{t} / \mathrm{m}^{3}, C=100 \mathrm{t} / \mathrm{m}^{2}, \phi=40^{\circ}$ 程度 と 見なされる。崩壊は，現地の状況より岩盤 すべりに近いものと思われるので，この值 を安定計算に用いる。

一方, この附近の崩壊発生率は, 既往調 查 ${ }^{25)}$ より, $P[F] \doteqdot 0.001$ である。これよ り(23)式を用いて， $\beta \doteqdot 3.10, \operatorname{CSSDP} 1$ に より Fscl $\doteqdot 2.277$ (図-4(h))。ここでは, 前節で述べたように，地震力を入力せず，
地下水もなしとして計算している。一方， $\tilde{F}_{S}$ は，前節 より，0〜0.7の平均值を取り $V_{D}=0.35$ を用いて，(22） 式より,

$$
\begin{gathered}
\tilde{F}_{S}=\sqrt{2} \times 3.10 \times 0.35+1 \doteqdot 2.53 \\
\quad \therefore \quad \tilde{F}_{S}>F_{s c} l \quad \ldots \ldots \ldots \ldots \ldots \ldots \ldots \ldots \ldots \ldots \ldots
\end{gathered}
$$

となる。

従って, この斜面の崩壊に対する 安全率は，周囲の （あるいは時系列的な）平均よりも小さく，危険である と判別し得る。

\section{6. 初生すべりの危険度判定}

次に，いままで述べて米た CSSDP 1 と信頼性解析を 用いた初生すべりの危険度判定手順を示す。手順は次の 二つに大別できる。

1）地形・地質要因による危険区域の抽出（スクリー ニング $)^{20}$

地質や斜面勾配每の発生率 $P[F]$ を用い，安全な斜面 を除外する。

2）重要な斜面もしくは特に崩壊発生率 $P[F]$ が高い

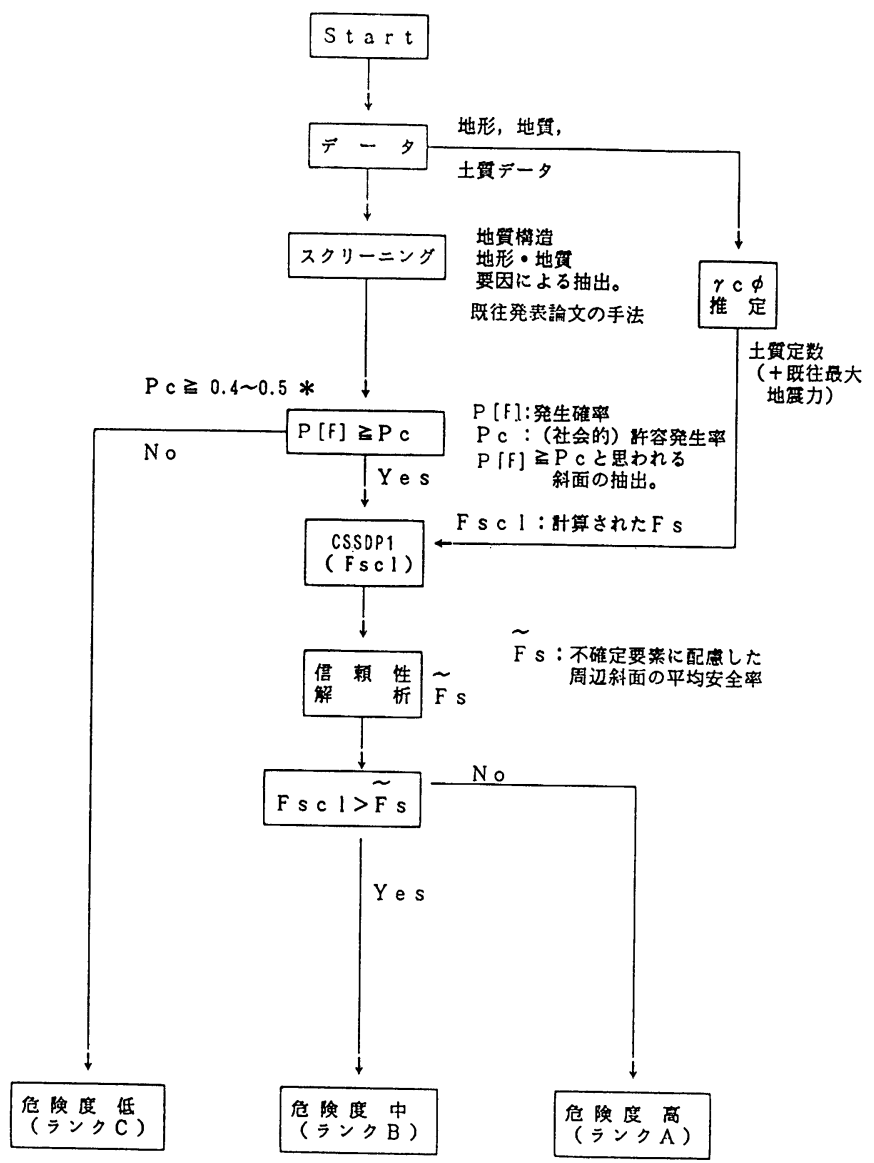

图-5危険度判定フロー

Fig. 5 Flow chart of Investigation 
と1)より判断される斜面の CSSDP 1 による解析（5.1，

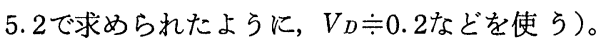

具体的なフローを図-5に示す。許容発生率 $P_{c}$ の合理

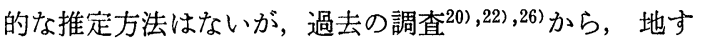
ベり・崩壊の発生率が, 周辺地域より高いと思われる值 である $P_{c}=0.4 \sim 0.5$ 程度で良いと思われる。この $P_{c}$ や CSSDP 1 の解析から得られる Fscl により, 図-5の ように危険度ランク分けもできると思われる。つまり， $P[F]$ を用いて, スクリーニングをする際, 特に発生率 が高くないと判断されたものは，危険度低（ランクC） とし, CSSDP 1 の計算結果より, 平均的な安全率より 安全率が高い $\left(F s c l>F_{S}\right)$ と判断されるものを危険度中 (ランク B)，それ以外を危険度高（ランク A）とする。 ただし，特定斜面の抽出に当っては， $P_{c}$ のみならず, 現地の実状を勘案して, 安定解析に供する斜面の範囲を 決めなければならない。

\section{7. 結 語}

ここで述べた手法は, 初生すべりの危険度を地形・地 質など素因で判定するのみでなく，地震動や間隙水圧の 上昇など誘因も，その概念の中に配慮し得る手法であり， 初生すべりの危険度判定に非常に有用であると考えられ る。今後は, 使用する $V_{D}$ の精度を上げるための事例解 析を行って行く必要があろう。

末尾ながら，本稿に対し貴重な御意見をいただいた京 都大学農学部林学科砂防学研究室の小橋澄治教授に感謝 いたします。

\section{参考文献}

1) 中村浩之, 吉松弘行, 久保田哲也, 中嶋 茂: 既往地すへ り災害実態調查, 上木研究所資料第2241号, 1985

2) Kawakami, H. : Landslide Risk Mapping by Quantification Method, Proc. IV ISL, Toront, Vol.2, 1984

3) Fujita, T. : Slope Analysis of Landslides in SHIKO. KU, Japan, proc. I.S.L., New Delhi, 1980

4) Styles, K.A. et.al. : (Hong Kong Geotechnical Control Office.) Terrain Classification Methods for Development planning \& Geotechnical Appraisal: A Hong Kong Case. IV International symposium on Landslides, Toront 1984. Vol.1. pp.561 568

5）田中耕平：地震によるランドスライド発生予測図一その現 状と問題点一, 地すべり, Vol.19, No.2, 1982

6) Ward, T.J. et al : Landslide potential and probability considering randomness of controlling factors. In :
Proc. Int. Symp. on Risk and Reliability in Water Resources, 26-28 June 1978, 2 (E.A.McBean, Ed.), University of Waterloo, Wataerloo, Canada, 592608

7) Leshchinsky, D., Baker., Silver, M.L.; Three Dimensional Analysis of Slope Stability, International Journal for Numerical and Analytical Methods in Geomechanics, Vol.9, pp.199 223, 1985

8）鵜飼恵三, 細堀健司 : 不均質粘土斜面の三次元安定解析, 第20回土質工学研究発表会講演論文集, pp.1443 1446, 1985

9）鍋島一郎：動的計画法, 数学ライブラリー7, 㷊北出版, 1968

10）申潤 植，板垣 治：地すべり(その 4), 土と基礎, Vol. 31, No.7, 1983

11) Baker, R. : Determination of the critical ship surface in slope stability computations; International Journal for Numerical and Analytical Methods in geomechanics, Vol.4, pp.333 359, 1980

12）山上拓男, 植田康宏 : Noncircular Slip Surface Analysis of Stability of Slopes - An Application of Dynamic Programming to the Janbu Method一; 地すべり 第22巻, 第 4 号, 1986

13) Arai, K. : Determination of noncircular slip surface giving the minimum factor of safety in slope stability analysis, Soil and Foundation, Vol.25, No.1, pp. 43 51, 1985

14）中村浩之, 久保田哲也：動的計画法を用いた臨界すべり面 解析法, 土木研究所資料第 2425 号, 1987

15) Whitman, R.V. : Evaluating Calculated Risk in Geotecnical Engineering, Proc. ASCE, GT 110, No.2, 1984

16）建設省土木研究所：地震化伴 5 大規模斜面崩塤に関する研 究, 土木研究所資料第 2544 号, 1988

17）谷口, 久保田, 桑原 : 長野県西部地震による松越地区の斜 面崩壊, 土之基礎，33-11，1985

18）久保田ら：成圈火山に扣ける大規模崩壊機構について, 平 成 2 年砂防学会研究発表会講演集, 1990

19）建設省日光砂防工事事務所：稲荷川流域崩壊調查，1982

20）中村浩之, 久保田哲也：地すべり危険箇所について, 地す ベり、Vol.23-4, 1987

21）中村浩之, 久保田哲也：Chen \& Chameau 法に上る地す べり斜面の三次元安定解析法, 土木研究所資料第 2281 号, 1986. pp.19 23

22）久保田哲也：糸魚川・静岡構造線周辺の崩壊特性について, 第28回地すべり学会研究発表会講演集, 1989

23）中村浩之, 久保田哲也, 吉田克美 : 怒田・八畧地域地すべ り調査, 昭和61年度土木研究所年次報告, 1986

24）三木幸蔵：わかりやすい岩石と岩盤の知識, 鹿島出版会, p.209, 1982

25）建設省日光砂防工事事務所：男鹿川流域崩壊調查報告書, 1982

26）久保田哲也：糸魚川・静岡構造線周辺の崩壊特性について, 第27回地すべり学会研究発表会講演集, 1988 （原稿受理日 平成 2 年 7 月 12 日） 
squeeze 型地すべりの発生機構－1923年根府川駅地すべり-

「地すべり」Vol. 27, No. 4 (通巻第104号) 1991年（平成 3 年） 3 月

金井 俊孝

squeeze 型地すべりとは，破壊した弱層が前方や側方に上位層よりる大きく絞り出されるように変形し，上位 層を含む斜面全体がそれに引き続いて崩壊するタイプの地すべりである。これらは，上下を硬い地層で挟まれた 10度以下の緩傾斜の弱層が, 地震や豪雨により急速に破壊した場合に発生すると考えられる。1923年関東地震に より発生した根府川駅地すべりはその実例であり, 弾塑性有限要素解析の結果, 破壊時には軽石層（弱層）の前 面で squeeze タイプの変形が発生したと推定される。また，単純な斜面の 3 層モデルを用いた検討においても， squeeze タイプの変形が地㞒の傾斜のかなり広い範囲で認められた。このような地すべりは, 弱層が緩傾斜で急 斜面に露出する古い成㬝火山の山麓で発生する可能性が高く，末端部はしばしば泥流化し，流動性に富む土砂が 比較的遠方まで達する。このことは, 火山地域に扰いて土砂災害の及ぶ範囲を予測する場合, 防災上重要な点に

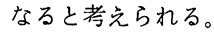

空中写真測量による地すべり情報の提供とすべり面の解析

一長野市広瀬地区に発生した地すべり地への応用一

「地すべり」Vol. 27，No. 4 (通巻第104号) 1991年（平成 3 年）3 月

吉澤孝和，丸山昌義，長尾 勲，村瀬孝三，西澤茂高，三澤敏雄，根岸六郎

臨界すべり面解析と信頼性解析を応用した地すべり・崩壊危険度の判定法

「地すべり」Vol. 27，No. 4 (通巻第104号) 1991年（平成 3 年）3 月

久保田哲也, 中村 浩之

従来から地すべり・崩壊危険度判定に用いられている地形・地質要素を用いた方法と, 動的計画法に基づく臨 界すべり面解析ならびに信頼性解析を応用した方法を組み合わせた仜険度判定法を検討した。

液状化による崩壊の発生について一中場大崩壊をケーススタディとして一

「地すべり」Vol. 27，No. 4 (通巻第104号) 1991年（平成 3 年）3 月

日浦 啓全, 佐々 恭二, 大手 桂二, 海堀 正博

昭和 58 年 7 月に島根県下を襲った率雨では幾多の崩壊や土石流が発生した。中場地区で発生した崩壊は不透水 性の岩脈と透水性の岩脈との間で発生した大規模なものであった。崩壊土砂の堆積状況, 形状から多量の水が関 与していた流動性の高い崩壊であることが解った。また，崩壊の機構として土層の一部で非排水載荷による液状 化が生じていた可能性があったため, これを三軸圧縮試験により確かめ, 上の粒度特性が液状化に刘して最も影 響の強い因子であることを明らかにした。

地すべり地盤の変形に及ぽす間隙水圧の影響についての一考察

「地すべり」Vol. 27, No. 4 (通巻第104号) 1991年（平成 3 年） 3 月

川邅 洋, 芝野 博文, 西尾 邦彦, 山口伊佐夫 